\section{Root Production of Seedling Grasses in Soil Containing Picloram $^{1}$}

\author{
C. J. SCIFRES AND J. C. HALIFAX ${ }^{2}$ \\ Assistant Professor and Graduate Research Assistant, \\ Department of Range Science, Texas A $\leftrightarrow M$ University, \\ College Station.
}

\section{Highlight}

Root production of switchgrass (Panicum virgatum L.) seedlings was decreased when 1 or $2 \mathrm{ppm}$ picloram were placed on the soil surface or at a depth of 3 inches. Root: shoot ratios by weight of switchgrass were decreased when picloram was placed on the surface or in the third inch of soil but were not affected by placement at 6 inches. Root production of sideoats grama (Bouteloua curtipendula (Michx.) Torr.) was decreased by picloram placed in the surface inch of soil. However, sideoats grama root production was increased in soil with $1 \mathrm{ppm}$ picloram in the sixth inch. Root:shoot ratios of sideoats grama in treated soil were usually no different than those of seedlings grown in untreated soil but rooting pattern was affected.

Combinations of 4-amino-3,5,6-trichloropicolinic acid (picloram), an experimental herbicide, with chlorophenoxyacetic acid herbicides effectively control a wide spectrum of undesirable woody species and herbaceous weeds. Relatively little research has been concerned with the reaction of desirable species in rangeland ecosystems to picloram. Preemergence applications of picloram controlled several species of warm-season grass seedlings including sideoats grama (Bouteloua curtipendula (Michx.) Torr.) and switchgrass (Panicum virgatum L.) (Arnold and Santelmann, 1966). However, applications of $1.5 \mathrm{lb}$./acre or less after the grass seedlings developed 2 to 4 true leaves did not reduce production of topgrowth. McCarty and Scifres (1968) reported that fall applications of picloram were more injurious to smooth bromegrass (Bromus inermis Leyss.) than spring applications regardless of rate. Smooth-bromegrass damage was attributed to root uptake of picloram. According to McCarty et al. (1967), picloram in combination with 3-amino-1,2,4-triazole (amitrole) retarded vegetative production and caryopsis yields of sideoats grama.

Recent research has emphasized the persistence of picloram in grassland ecosystems. Soil residues were usually restricted to the surface foot for 60 days following application of $0.25 \mathrm{lb}$./acre of picloram in the Rolling Plains of Texas (Scifres et al., 1971b). Concentrations were about $2 \mathrm{ppm}$ in the

${ }^{1}$ Approved by the Director, Texas Agricultural Experiment Station as TA-9106. Received April 26, 1971.

${ }^{2}$ The authors appreciate the cooperation of J. Priddy and the George Warner Seed Company, Hereford, Texas, who supplied the caryopses for this study. surface inch of soil the day of application. Picloram dissipated from aerial portions of grasses within 60 days after application (Scifres et al., 197la). Data indicated that grasses absorbed picloram from the soil without affecting forage production.

Factors providing impetus for the present study were soil residues following picloram application to rangelands and sensitivity of some grass seedlings to picloram. The influence of picloram residues on root production, rooting depth, and root:shoot ratios in switchgrass and sideoats grama seedlings was evaluated.

\section{Materials and Methods}

Opaque-polyethylene tubes, 3 inches in diameter and 18 inches long, were filled with a sand-clay loam (1:4) mixture to within 7 inches of the top. Technical-grade picloram $(99 \%)$ in aqueous solution was incorporated with additional portions of the soil mixture at 1 or $2 \mathrm{ppm}$ on a wt/wt basis. One-inch layers of picloram-treated soil were placed at depths of either 6 inches, 3 inches or on the soil surface in the tubes. One gram of switchgrass cultivar "Blackwell" or sideoats grama cultivar "Premier" seeds were planted on the soil surface and covered with $5 \mathrm{~mm}$ of sand. The base of each tube was placed in a plastic cup. Sprinkler irrigation was applied as necessary to germinate the seeds and maintain vigorous seedling growth. Picloram treatments were triplicated for each species in randomized complete block designs.

Emergence and seedling growth were observed weekly. Seedlings in each tube were assigned a numerical rating where " 0 " indicated no symptoms of phytoxicity and " 100 " indicated no emergence or complete mortality. Fresh weights of seedling topgrowth were recorded after 21 days. The soil was then removed from each tube as an intact core and arbitrarily divided in sections, 0 to 3,3 to 6 and 6 to 12 inches long from the surface. Soil sections were placed in $5 \mathrm{~mm}$ sieves and soaked to separate roots from soil. The roots were blotted dry and fresh weights recorded.

Glass-front boxes were planted to each species and root elongation measured. The box fronts were covered to prevent light entry between root measurements. The surface inch of soil mixture was treated with 0,1 or $2 \mathrm{ppm}$ picloram prior to planting seeds in one set of glass-front boxes. Average penetration depth of grass roots was recorded at threeday intervals. Each treatment was duplicated for each species in a completely random design.

Each experiment was conducted twice and data pooled for statistical analyses. Root yields were converted to percentage of untreated seedlings by sampling depth for presentation. An inverse-sine tranformation was applied to percentage data before conducting analysis of variance as suggested by Steel and Torrie (1960).

\section{Results and Discussion}

Topgrowth of switchgrass seedlings was chlorotic shortly after emergence from soil with picloram in the surface inch. Switchgrass seedlings, after 21 days in soil with picloram on the surface or at a depth of 3 inches, displayed more phytoxicity than those grown in soil with picloram at 6 
Table 1. Ratings of phytoxicity symptoms in topgrowth of switchgrass and sideoats grama seedlings 21 days after planting in soil containing 1 or $2 \mathrm{ppm}$ picloram at various depths (inches).

\begin{tabular}{cccc}
\hline \hline \multirow{2}{*}{$\begin{array}{c}\text { Picloram } \\
\text { concentration }\end{array}$} & $\begin{array}{c}\text { Picloram } \\
\text { depth }\end{array}$ & \multicolumn{2}{c}{ Symptom rating $^{1}$} \\
\cline { 3 - 4 } & - & 0 & Switchgrass \\
\hline 0 & $0-1$ & 40 & Sideoats grama \\
1 & $3-4$ & 32 & 10 \\
& $6-7$ & 3 & 7 \\
& $0-1$ & 58 & 7 \\
2 & $3-4$ & 57 & 7 \\
& $6-7$ & 13 & 0
\end{tabular}

1 Average rating where " 0 " indicates no symptoms of phototoxicity and "100" indicates all seedlings dead or failed to emerge.

inches (Table 1). Symptoms in switchgrass topgrowth developed about a week sooner when picloram was on the surface than when it was in the third inch of soil. Roots reached the third inch 5 or 6 days after planting and some were 6 inches deep after a week (Fig. 1). Picloram symptoms in topgrowth were usually noted within 2 days after switchgrass roots penetrated treated soil. Reaction of switchgrass topgrowth to picloram placed at 6 inches varied between experiments. Slight epinasty of coleoptiles, a common symptom in petioles and meristematic tissues of broadleaved species treated with picloram, was noted in the first study within 10 days after emergence. However, epinasty did not develop in seedlings in the second study. This differential may have been due to removal of the picloram by leaching in the second study; an important method of dissipation under field conditions (Scifres et al., 1971b).

Sideoats grama topgrowth was less susceptible to picloram residues regardless of concentration or

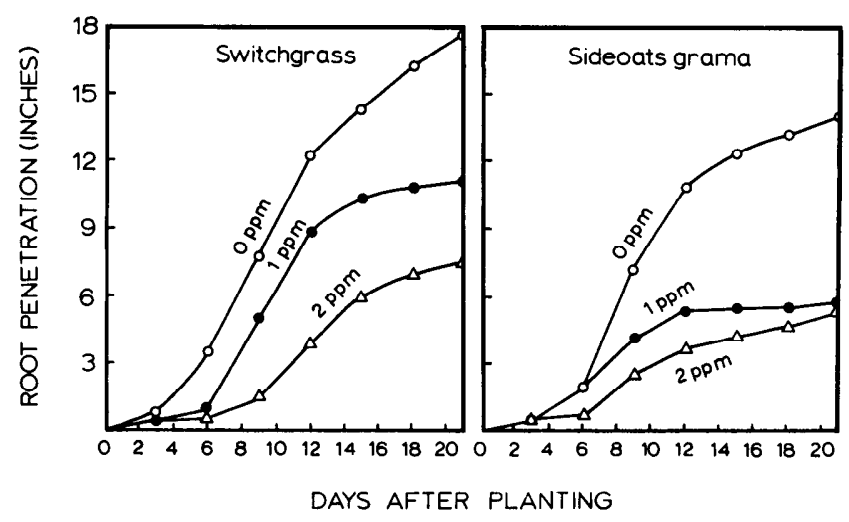

Fig. 1. Average root penetration of switchgrass and sideoats grama seedlings when the surface inch of soil contained picloram at 0,1 or $2 \mathrm{ppm}$.
Table 2. Root production (\%) of switchgrass seedlings 21 days after planting in soil containing 1 or $2 \mathrm{ppm}$ picloram at various depths (inches). ${ }^{1}$

\begin{tabular}{cccccc}
\hline \hline \multicolumn{2}{c}{ Picloram } & & \multicolumn{3}{c}{ Soil layer $^{2}$} \\
\cline { 1 - 2 } \cline { 5 - 6 } Concentration & Dcpth & & $0-3$ & $3-6$ & $6-12$ \\
\hline 0 & - & & $100 \mathrm{a}$ & $100 \mathrm{a}$ & $100 \mathrm{a}$ \\
1 & $0-1$ & & $24 \mathrm{efg}$ & $42 \mathrm{de}$ & $19 \mathrm{fg}$ \\
& $3-4$ & & $64 \mathrm{bc}$ & $53 \mathrm{~cd}$ & $55 \mathrm{~cd}$ \\
& $6-7$ & & $97 \mathrm{a}$ & $89 \mathrm{a}$ & $50 \mathrm{~cd}$ \\
2 & $0-1$ & & $9 \mathrm{~g}$ & $20 \mathrm{fg}$ & $17 \mathrm{~g}$ \\
& $3-1$ & & $41 \mathrm{cde}$ & $45 \mathrm{cde}$ & $61 \mathrm{~cd}$ \\
& $6-7$ & & $81 \mathrm{ab}$ & $55 \mathrm{~cd}$ & $40 \mathrm{def}$ \\
\hline
\end{tabular}

placement depth, than switchgrass (Table 1). Slight chlorosis developed in sideoats grama seedlings 21 days after planting in soil containing picloram on the surface or at a depth of 3 inches. Sideoats grama roots were recorded at a depth of 3 inches a week after planting and were present at 6 inches 2 to 3 days later (Fig. 1). Epinasty developed in sideoats grama coleoptiles shortly after emergence when picloram was present on the soil surface. No symptoms of phytotoxicity were displayed 21 days after planting sideoats grama in soil containing picloram at 6 inches (Table 1 ).

Picloram in the surface inch of soil reduced root production of switchgrass seedlings at all depths (Table 2). Root production was greater in soil containing 1 than 2 ppm picloram. Root penetration was restricted to 12 inches or less when picloram was placed on the surface (Fig. 1). Greatest reductions in root production from $1 \mathrm{ppm}$ picloram on the soil surface occurred in the upper 3 inches and from the 6 to 12 -inch depth. Root elongation was most rapid at 3 to 6 inches regardless of picloram concentration. Placement of $2 \mathrm{ppm}$ picloram on the soil surface decreased root production of switchgrass 80 to $90 \%$ at all depths.

Root production of switchgrass at all depths was greater when picloram was placed at a depth of 3 inches than on the soil surface, regardless of concentration (Table 2). However, root production was decreased 50 to $60 \%$ at all depths with this placement. Picloram at a depth of 6 inches did not significantly decrease root production of switchgrass seedlings in the surface 3 inches of soil at a concentration of $2 \mathrm{ppm}$ or in the surface 6 inches at $1 \mathrm{ppm}$. IIowever, root production decreased about $50 \%$ in the 6 to 12 -inch zone when picloram was placed at a depth of 6 inches. 
Table 3. Root production (\%) of sideoats grama seedlings 21 days after planting in soil containing 1 or 2 ppm picloram placed at various depths (inches). ${ }^{1}$

\begin{tabular}{cccccc}
\hline \hline \multicolumn{2}{c}{ Picloram } & & \multicolumn{3}{c}{ Soil layer } \\
\cline { 1 - 2 } \cline { 5 - 6 } Concentration & Depth & & $0-3$ & $3-6$ & $6-12$ \\
\hline 0 & - & & $100 \mathrm{a}$ & $100 \mathrm{a}$ & $100 \mathrm{a}$ \\
$\mathrm{I}$ & $0-1$ & & $45 \mathrm{efg}$ & $45 \mathrm{efg}$ & $0 \mathrm{~h}$ \\
& $3-4$ & & $121 \mathrm{bc}$ & $59 \mathrm{e}$ & $0 \mathrm{~h}$ \\
& $6-7$ & & $146 \mathrm{a}$ & $135 \mathrm{ab}$ & $33 \mathrm{fg}$ \\
2 & $0-1$ & & $36 \mathrm{fg}$ & $7 \mathrm{~h}$ & $0 \mathrm{~h}$ \\
& $3-4$ & & $56 \mathrm{ef}$ & $23 \mathrm{gh}$ & $4 \mathrm{~h}$ \\
& $6-7$ & & $153 \mathrm{a}$ & $88 \mathrm{~d}$ & $6 \mathrm{~h}$
\end{tabular}

${ }^{1}$ Means represent percentage by weight of roots produced by untreated seedlings at each depth.

2 Means followed by the same letter arc not significantly different at the $5 \%$ level.

Root production of sideoats grama seedlings was decreased most when picloram was placed on the soil surface (Table 3). When 1 ppm of picloram was placed on the soil surface and $2 \mathrm{ppm}$ were placed at a depth of 3 inches, similar reductions in root production occurred. Root production was severely inhibited or prevented in the 6 to 12-inch zone regardless of picloram concentration or placement depth. Although sideoats grama roots penetrated to a depth of 14 inches in untreated soil, restriction in root penetration to 6 inches was noted when seedlings were grown in soil with picloram on the surface (Fig. 1). However, when either picloram concentration was placed 6 inches deep and when 1 ppm was placed 3 inches deep, root production increased as compared to that of untreated seedlings in the surface 3 inches of soil (Table 3 ).

Relatively low root:shoot ratios based on weight of switchgrass seedlings indicated that foliage was developed at the expense of root production when picloram was placed in the soil (Table 4). Root: shoot ratios indicated no differential inhibition of sideoats grama roots and shoots although depth of penetration was reduced when picloram was placed in the surface inch of soil. Most root:shoot ratios from sideoats grama were near 1.0. Thus, the primary influence of picloram was in changing rooting pattern. The only root:shoot ratio different from that of untreated sideoats grama seedlings resulted from placing $1 \mathrm{ppm}$ of picloram 6 inches deep. Increased root:shoot ratios when 1 ppm was placed at depths of 3 or 6 inches and 2 ppm were placed at 6 inches reflected increased root production in the surface 3 inches of soil.

Differential susceptibility of grass species to picloram, similar to that between switchgrass and
Table 4. Root:shoot ratios by weight (g) of switchgrass and sideoats grama seedlings 21 days after planting in soil containing 1 or $2 \mathrm{ppm}$ picloram at various depths (inches). 1

\begin{tabular}{ccccc}
\hline \hline \multicolumn{2}{c}{ Picloram } & & & \\
\hline Concentration & Depth & & Switchgrass & Sideoats grama \\
\hline 0 & - & $0.98 \mathrm{a}$ & $0.96 \mathrm{x}$ \\
1 & $0-1$ & $0.46 \mathrm{c}$ & $0.94 \mathrm{x}$ \\
& $3-4$ & $0.71 \mathrm{abc}$ & $1.13 \mathrm{xy}$ \\
& $6-7$ & $0.92 \mathrm{a}$ & $1.38 \mathrm{y}$ \\
2 & $0-1$ & $0.36 \mathrm{c}$ & $0.86 \mathrm{x}$ \\
& $3-4$ & $0.56 \mathrm{bc}$ & $0.87 \mathrm{x}$ \\
& $6-7$ & $0.87 \mathrm{ab}$ & $1.10 \mathrm{xy}$ \\
\hline
\end{tabular}

1 Means followed by the same letter are not significantly different at the $5 \%$ level.

sideoats grama, has been noted in sorghum (Scifres and Bovey, 1970). The auxin-type influence of picloram on range grasses warrants further research. Variation in root production of switchgrass and sideoats grama seedlings in soil treated with picloram depends on location and concentration of residues. Success from range seedings is often limited by minimal yearly precipitation, summer droughts and insect damage (Robocker et al., 1965). These data indicate that picloram applied just prior to or following range seeding or applied to badly depleted rangeland could further complicate rate of seedling establishment.

\section{Literature Cited}

Arnold, W. R., and P. W. Santelmann. 1966. The response of native grasses and forbs to picloram. Weeds 14:74-76.

McCarty, M. K., and C. J. Scifres. 1968. Smooth bromegrass response to herbicides as affected by time of application in relation to nitrogen fertilization. Weed Sci. 16:443-446.

McCarty, M. K., L. C. Newell, C. J. Scifres, and J. E. Congrove. 1967. Weed control in seed fields of sideoats grama. Weeds 15:171-174.

Robocker, W. C., D. H. Gates, and H. D. Kerr. 1965. Effects of herbicides, burning, and seeding date in reseeding arid range. J. Range Manage. 18:114-118.

Scifres, C. J., AND R. W. Bovey. 1970. Differential responses of sorghum varieties to picloram. Agron. J. 63: 775-777.

Scifres, C. J., R. R. Hahn, and M. G. Merkle. 1971a. Dissipation of picloram from vegetation of semiarid rangelands. Weed Sci. 19:329-332.

Scifres, C. J., R. R. Hahn, J. Diaz-Colon, and M. G. Merkle. 1971b. Picloram persistence in semiarid rangeland soils and water. Weed Sci. 19:381-384.

Steel, R. G. D., ANd J. H. Torrie. 1960. Principles and procedures of statistics. McGraw-Hill Book Company, Inc., New York. 481 p. 